\title{
Contents of Volume 92 (1977)
}

\section{AUTHORS AND TITLES}

Alford, John A. (Michigan State Univ.). Literature and Law in Medieval

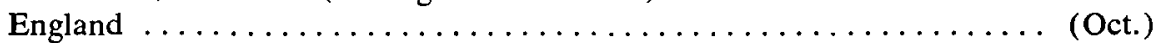
APRoBERTS, RUTH (Univ. of California, Riverside), Old Testament Poetry: The

Translatable Structure ........................ (Oct.)

Arac, Jonathan (Princeton Univ.). The Form of Carnival in Under the Vol-

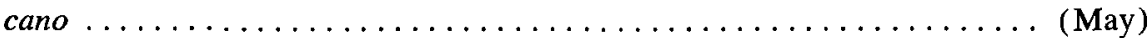

Barge, Laura (Mississippi State Univ.). "Coloured Images" in the "Black

Dark": Samuel Beckett's Later Fiction ................... (March)

BenNetT, JoAn S. (Univ. of Delaware). God, Satan, and King Charles: Milton's

Royal Portraits .......................... (May)

Berry, Alice FIola (Washington Univ.). "Les Mithologies Pantagruelicques":

Introduction to a Study of Rabelais's Quart livre ............... (May)

Christensen, Jerome C. (Purdue Univ.). Coleridge's Marginal Method in

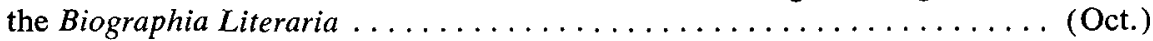

Coetzee, John M. (Univ. of Cape Town). Achterberg's "Ballade van de gas-

fitter": The Mystery of I and You ................... (March)

Delany, Paul (Simon Fraser Univ.). King Lear and the Decline of Feudalism $\ldots \ldots \ldots \ldots \ldots \ldots \ldots \ldots \ldots \ldots \ldots \ldots \ldots \ldots \ldots \ldots \ldots \ldots \ldots$ (May)

Dye, Robert Ellis (Macalester Coll.). The Easter Cantata and the Idea of Mediation in Goethe's Faust ..................... (Oct.) EAves, Morris (Univ. of New Mexico). Blake and the Artistic Machine: An

Essay in Decorum and Technology ................... (Oct.)

Firchow, Peter E. (Univ. of Minnesota, Minneapolis). Private Faces in Public

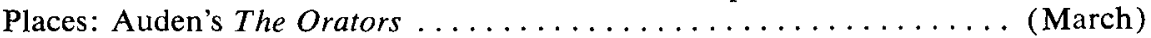

Fixler, Michael (Tufts Univ.). Plato's Four Furors and the Real Structure of

Paradise Lost . . . . . . . . . . . . . . . . . . . . . . . . . (Oct.)

Frye, Northrop (Univ. of Toronto). Presidential Address 1976 . . . . (May)

GrifFIN, ANDREw L. (Univ. of California, Berkeley). Wordsworth and the

Problem of Imaginative Story: The Case of "Simon Lee" . . . . . . . . . (May)

Gutwirth, Marcel (Haverford Coll.). Tartuffe and the Mysteries ..... (Jan.)

Joseph, Gerhard (Herbert H. Lehman Coll., City Univ. of New York). Tenny-

son's Optics: The Eagle's Gaze . . . . . . . . . . . . . . . . . (May)

Keyssar, Helene (Amherst Coll.). I Love You. Who Are You? The Strategy of

Drama in Recognition Scenes .................... (March)

KoRg, JACOB (Univ. of Washington). Hopkins' Linguistic Deviations . . . (Oct.)

MacCannell, Juliet Flower (Davis, Calif.). Nature and Self-Love: A Reinterpretation of Rousseau's "Passion primitive" ............. (Oct.)

Matchett, William H. (Univ. of Washington). Shylock, Iago, and Sir Thomas

More: With Some Further Discussion of Shakespeare's Imagination . . . . (March)

McCarthy, William (Iowa State Univ.). The Continuity of Milton's Sonnets

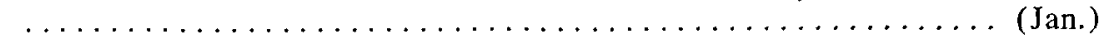

McIntosh, Carey (Brown Univ.). A Matter of Style: Stative and Dynamic

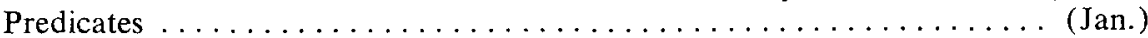

NeEly, Carol Thomas (Champaign, Ill.). Detachment and Engagement in

Shakespeare's Sonnets: 94,116 , and $129 \ldots \ldots \ldots \ldots \ldots \ldots \ldots \ldots$ (Jan.)

Novak, Maximillian E. (Univ. of California, Los Angeles). Defoe and the Dis-

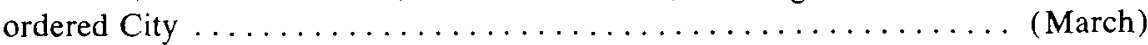

RAMSEY, JAROLD W. (Univ, of Rochester). The Wife Who Goes Out like a Man, Comes Back as a Hero: The Art of Two Oregon Indian Narratives . ..... (Jan.)

941

987

481

273

441

471

928

285

429

963

903

253

952

385

392

420

977

890

96 


\section{Contents of Volume 92}

Samuel, Irene (New York, N.Y.). The Development of Milton's Poetics

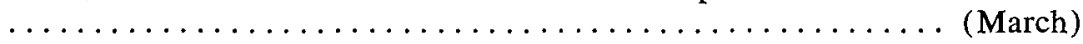

Simmons, J. L. (Tulane Univ.). The Tongue and Its Office in The Revenger's

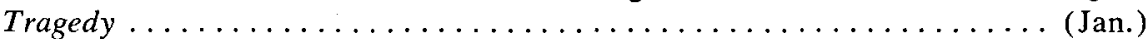

Suleiman, Susan (Occidental Coll.). The Parenthetical Function in $A$ la re-

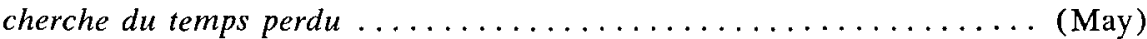

Sussman, Henry (Johns Hopkins Univ.). The Court as Text: Inversion, Supplanting, and Derangement in Kafka's Der Prozeß .................. (Jan.)

WALDOFF, LEON (Univ. of Illinois, Urbana). The Theme of Mutability in the

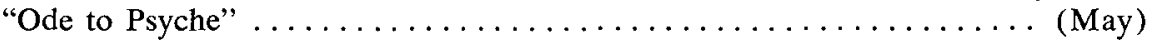

WILT, Judith (Princeton Univ.). He Could Go No Farther: A Modest Proposal about Lovelace and Clarissa .......................... (Jan.)

Wimsatt, JAMEs I. (Univ. of North Carolina, Greensboro). Medieval and Mod-

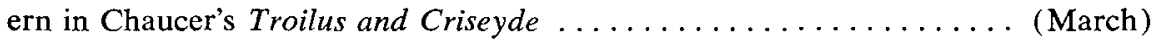

Wolfley, LaWrence C. (Oakland, Calif.). Repression's Rainbow: The Presence of Norman O. Brown in Pynchon's Big Novel ............... (Oct.)

Woodring, Carl (Columbia Univ.). Nature and Art in the Nineteenth Century

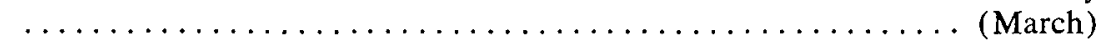

Zwerdling, Alex (Univ. of California, Berkeley). Mrs. Dalloway and the

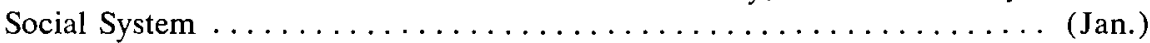

\section{MISCELLANEOUS}

Center for Scholarly Editions: An Introductory Statement .... (Dir.)

Chatrmen and Directors of Ethniç Studies Programs ......... (Dir.)

Chairmen of Language and Area Programs $\ldots \ldots \ldots \ldots \ldots \ldots$ (Dir.)

Commitrees and Commissions of the Association ............ (Dir.)

Constitution of the Modern Language Association of America: A ProPOSED AMENDMENT $\ldots \ldots \ldots \ldots \ldots \ldots \ldots \ldots \ldots \ldots \ldots \ldots \ldots \ldots \ldots \ldots \ldots \ldots \ldots$ (Dir.)

DiRECTORY OF UsEFUl AdDRESSES, $1977-78 \ldots \ldots \ldots \ldots \ldots \ldots \ldots$ (Dir.)

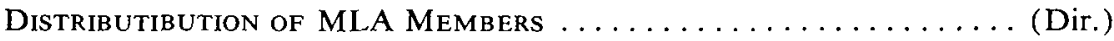

Editor's Column ........... (Jan.) 3, (March) 187, (May) 379, (Oct.)

English and Foreign Language Department Chairmen, 1977-78

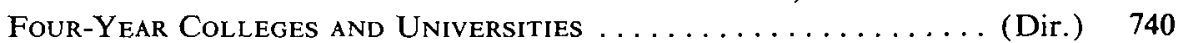

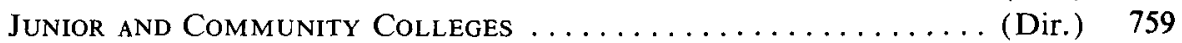

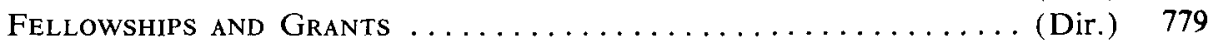

Forum .................. (Jan.) 122, (March) 307, (May) 490, (Oct.) 1005

Honorary Fellows of the Modern language association of america

Honorary Members of the Modern Language association of america

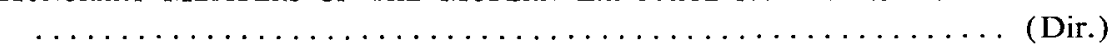

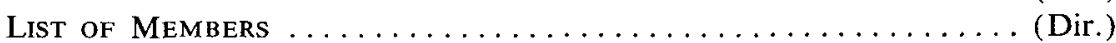

Members of the Executive Council $\ldots \ldots \ldots \ldots \ldots \ldots \ldots$ (Dir.)

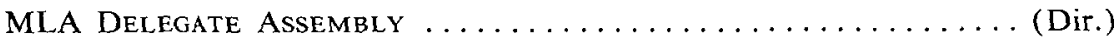

MLA Divisions and Discussion Groups $\ldots \ldots \ldots \ldots \ldots \ldots \ldots$ (Dir.)

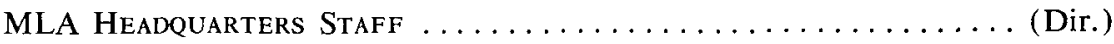

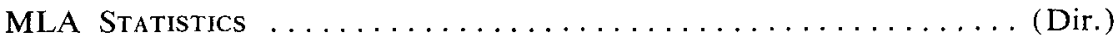

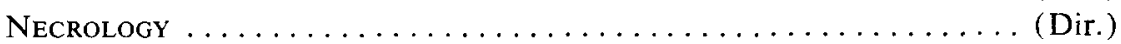

Presidents of the Association, $1884-1977 \ldots \ldots \ldots \ldots \ldots \ldots \ldots$ (Dir.)

Professional Notes and Comments $\ldots \ldots \ldots \ldots \ldots \ldots \ldots \ldots \ldots \ldots$ .............. (Jan.) 138, (March) 318, (May) 510, (Dir.) 800, (Oct.) 1026

RePORT OF THE EXecutive Director ..................... (May) 497

Reports of the Regional Modern language Associations ........ (Dir.) 598

Women's Studies Programs .......................... (Dir.) 774 
FOUR POSTWAR AMERICAN

NOVELISTS

Bellow, Mailer, Barth, and Pynchon

Frank D. McConnell

"McConnell provides perspectives that no other commentators

on current fiction have made available to us." - Harold

Bloom, Yale University 240 pages Cloth $\$ 15.00$

\section{THE COLLECTED POEMS OF HOWARD NEMEROV}

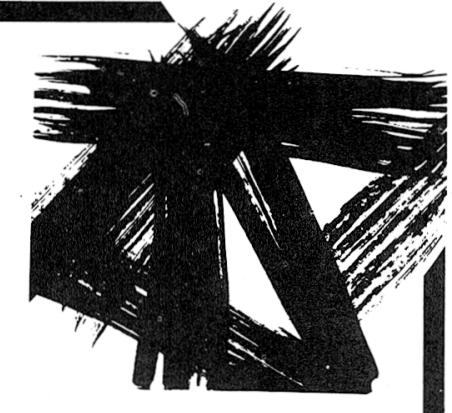

For nearly thirty years, Nemerov has given us poems whose intelligence, perspicacity, and wit have become his hallmarks. This volume presents them all, from 1947 to 1975.

560 pages Cloth $\$ 17.50$ to $12 / 31 / 77 ; \$ 20.00$ thereafter

\section{CARNIVAL}

Entertainments and Posthumous Tales

Isak Dinesen

Three of the tales translated by P. M. Mitchell and W. D. Paden

This important collection features stories, never before available in book form in English, drawn from all phases of Dinesen's writing career. $\quad 352$ pages Cloth $\$ 10.00$

\section{THE ROYAL GUEST}

and Other Classical Danish Narrative

Translated and Edited by P. M. Mitchell and Kenneth H. Ober

These new translations of six tales by four of Denmark's leading literary figures of the nineteenth century possess striking contemporary appeal. 256 pages Cloth $\$ 12.50$ October

\section{SAMUEL JOHNSON AND POETIC STYLE William Edinger}

"There is no other work that I know of that combines so firm a theoretical view of Johnson's critical work with so ample a demonstration of its historical relationships."-Jean $\mathrm{H}$. Hagstrum, Northwestern University 288 pages Cloth $\$ 17.00$ November

\section{ADVENTURE, MYSTERY, AND ROMANCE \\ Formula Stories as Art and Popular Culture \\ John G. Cawelti \\ "A major contribution to the scanty serious literature of popular culture... . Without doubt, a tour de force." -Garth S. Jowett, Journal of American History viii, 336 pages Paper $\$ 5.95$}

\section{HAWTHORNE, MELVILLE, AND THE NOVEL}

Richard H. Brodhead

"One of the very best books on American fiction to have appeared in the last decade or so."

-R. W. B. Lewis viii, 216 pages Paper $\$ 4.50$

\section{OLSON'S PENNY ARCADE}

\section{Elder Olson}

"Mr. Olson's very considerable abilities as scholar, philosopher, literary critic and aesthetic theoretician all go into the poems in perfectly amazing and meaningful ways."

-James Dickey $\quad x, 94$ pages Paper $\$ 2.95$ 


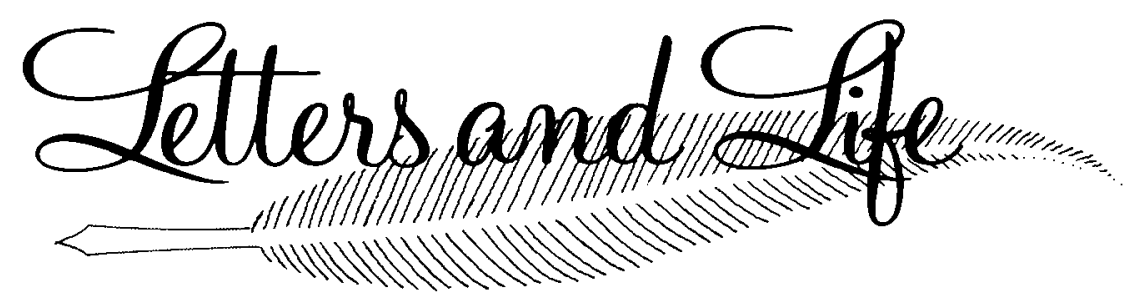

\section{THE MYSTERIES OF IDENTITY}

\section{A Theme in Modern Literature}

Robert Langbaum. University of Virginia. Blending intellectual history and literary criticism, Langbaum examines changing attitudes toward the question of identity in modern literature - specifically in the works of Wordsworth, Arnold, Eliot, Beckett, Yeats and Lawrence. \$13.95

\section{UNDER SIEGE}

\section{Literary Life in London,1939-45}

Robert Hewison. Exhilarating, frustrating, myth-making, cynical - all the diversity of intellectual and artistic life in the London of the Blitz is vividly evoked in this unusual, anecdote filled social and literary history. With 16 illustrations, $\$ 11.95$

\section{THE FIRE AND THE SUN}

\section{Why Plato Banished the Artists}

Iris Murdoch, Oxford University. The eminent philosopher and novelist takes a stimulating look at Plato's theories of art, providing a sympathetic explanation of his hostility to it and a wide-ranging discussion of the ways his thinking influenced later ideas about the role of art in society. $\$ 5.95$

\section{PAPERS TIGERS}

\section{The Ideal Fictions of Jorge Luis Borges}

John Sturrock. In analyzing the intricate short fictions of Borges, Sturrock finds narratives that do not simply dramatize ideas but also make important statements, in ingeniously dramatic form, about the very process by which narrative fiction is made. $\$ 12.95$ 